INTERNATIONAL FOOD

POLICY RESEARCH INSTITUTE

sustainable solutions for ending hunger and poverty

Supported by the CGIAR

IFPRI Discussion Paper 01123

September 2011

\title{
Measuring the Impacts of Global Trade Reform with Optimal Aggregators of Distortions
}

\author{
David Laborde \\ Will Martin \\ Dominique van der Mensbrugghe
}

Markets, Trade and Institutions Division 


\section{INTERNATIONAL FOOD POLICY RESEARCH INSTITUTE}

The International Food Policy Research Institute (IFPRI) was established in 1975. IFPRI is one of 15 agricultural research centers that receive principal funding from governments, private foundations, and international and regional organizations, most of which are members of the Consultative Group on International Agricultural Research (CGIAR).

\section{PARTNERS AND CONTRIBUTORS}

IFPRI gratefully acknowledges the generous unrestricted funding from Australia, Canada, China, Denmark, Finland, France, Germany, India, Ireland, Italy, Japan, the Netherlands, Norway, the Philippines, South Africa, Sweden, Switzerland, the United Kingdom, the United States, and the World Bank.

\section{AUTHORS}

David Laborde, International Food Policy Research Institute

Senior Research Fellow, Markets, Trade and Institutions Division

d.laborde@cgiar.org

Will Martin, The World Bank

Research Manager, Agriculture and Rural Development

Dominique van der Mensbrugghe, Food and Agriculture Organization of the United Nations Senior Economist, Agricultural Development Economics Division

Notices

IFPRI Discussion Papers contain preliminary material and research results. They have been peer reviewed, but have not been subject to a formal external review via IFPRl's Publications Review Committee. They are circulated in order to stimulate discussion and critical comment; any opinions expressed are those of the author(s) and do not necessarily reflect the policies or opinions of IFPRI.

Copyright 2011 International Food Policy Research Institute. All rights reserved. Sections of this material may be reproduced for personal and not-for-profit use without the express written permission of but with acknowledgment to IFPRI. To reproduce the material contained herein for profit or commercial use requires express written permission. To obtain permission, contact the Communications Division at ifpri-copyright@cgiar.org. 


\section{Contents}

Abstract $\quad$ V

Acknowledgments vi

1. Introduction 1

2. The Aggregation Approach 3

3. Qualitative Implications of Aggregation 6

4. Implementation $\quad 8$

5. Applications to Global Trade Reform 11

6. Sensitivity Analysis and Context 15

$\begin{array}{ll}\text { 7. Conclusions } & 19\end{array}$

$\begin{array}{ll}\text { References } & 20\end{array}$ 


\section{List of Tables}

5.1-Tariff aggregators: Tariff revenue and expenditure aggregators 12

5.2-Results for full liberalization: Central case, changes compared to baseline 13

5.3- Swiss formula vs. full liberalization: Real income, central case, changes from baseline US\$million

6.1-Full liberalization: Sensitivity analysis for $\sigma_{1} \quad 15$

6.2-Full liberalization: Sensitivity analysis for $\sigma_{2} \quad 17$

\section{List of Figures}

3.1-Marginal impacts of tariff reductions on expenditure and tariff revenues 


\begin{abstract}
Traditional weighted-average measures of trade distortions are widely used in analyzing global and regional reforms, despite well-known deficiencies. This paper develops and applies optimal aggregators for the real-world case of multiple countries and commodities with much more detailed information on trade than on production and consumption. The approach reflects that different aggregators are needed for expenditure on imported goods and tariff revenues, and allows for incorporation of both intensive and extensive margins of adjustment to reform. Applications confirm that the technique is straightforward enough for widespread use, and point to close to a doubling of the welfare gains at the intensive margin when using the highest possible level of international commodity disaggregation, with larger gains in developing regions than in the industrial countries. The measured income gains increase along the entire path of liberalization, with slightly larger increases in the earlier stages, where the gaps between the responses of the expenditure and tariff revenue aggregators are largest. Sensitivity analysis suggests that, for global trade reform, the ease of substitution between tariff lines is much more important than that between varieties from different countries.
\end{abstract}

Keywords: aggregation, distortions, economic welfare measurement, trade reform, trade restrictiveness

JEL Codes: C43, C68, D58, D61, F13, F17. 


\section{ACKNOWLEDGMENTS}

This paper reflects the views of the authors only and not those of IFPRI or the World Bank. 


\section{INTRODUCTION}

Economists have long been aware that the standard approaches used to assess the implications of largescale reforms, such as World Trade Organization (WTO) agreements, may seriously understate their benefits because of excessive aggregation of trade distortions. The problem is potentially important because border protection rates applied to finely differentiated products frequently differ greatly. ${ }^{1}$ It has proved difficult to resolve because the needed information on production and demand structures is typically available only at a much higher level of aggregation than the information on tariffs and trade flows and theoretically consistent approaches to aggregation have not been available.

Historically, measures such as simple or trade-weighted-average tariffs have frequently been employed to summarize trade policy distortions up to a level consistent with that used for analysis of production and consumption. As emphasized by Anderson and Neary (1996), these measures are without theoretical foundation and may introduce significant biases. The most obvious problem with the tradeweighted average is that the weight on any tariff declines as it rises, with high tariffs having vanishingly small weights even when their trade-distorting impacts may be large. As we show in this paper, these standard tariff aggregators have another fundamental problem in failing to take into account the tariff revenue-enhancing effects of within-group increases in import quantities associated with tariff cuts on highly protected goods. The first problem is clearly serious when liberalization reduces tariffs substantially from their initial level. The second problem is most serious in the initial stages of liberalization, when tariffs are at their highest.

In recent years, new and theoretically consistent approaches to the aggregation problem have emerged. Anderson and Neary (1994) proposed a uniform tariff that yields the same welfare as the original differentiated tariff structure. In subsequent work (2003), they developed uniform tariff measures that are optimal for measuring effects on trade volumes. The unifying feature of these aggregators is that they return the uniform tariff rates that are optimal in the sense of yielding the same value of a specific objective function as the actual, nonuniform trade distortions.

Building on the Anderson-Neary approach, Bach, Martin, and Stevens (1996) and Bach and Martin (2001) proposed an approach to aggregation in the context of structural economic models that mitigates many of the problems resulting from use of atheoretic aggregators - and showed that the implications of aggregation could be large for specific countries. However, they were only able to apply their approach to individual countries or regions. Martin, van der Mensbrugghe, and Manole (2003) applied this methodology to additional countries and confirmed that the impact on the results could be substantial. Manole and Martin (2005) developed the approach further, showing that it should be applied in specific ways and establishing relationships between different tariff indexes. Anderson (2009) made an important step forward in identifying an approach that enables optimal aggregators to be used in multicountry and global models.

Anderson (2009) showed that an optimal approach to aggregation dramatically increased the measured welfare benefits of trade reform relative to results obtained with a two-sector model in a highly protected country (pre-reform India). A key question that remains is how large this aggregation bias might be in models of the type usually used to analyze global trade reforms, where perhaps 20 or 25 sectors are separately identified. A second key question is what parameter estimates are needed to implement it and to which of these parameters are the results most likely to be sensitive. A third question is for which types of policy reform this approach is most likely to make a difference. Are, in particular, its impacts greatest for partial reform or for full liberalization? A final question that we address is how extensive-margin adjustments involving new products or varieties might be included, and how important the intensivemargin adjustment on which we focus in our quantitative analysis might be relative to approaches that add adjustments to the range of products traded (see Debaere and Mostashari 2010).

In Section 1, we outline the approach to aggregation used in this paper, taking particular care to provide an accessible formulation for use in applied models. In Section 2, we consider the qualitative

\footnotetext{
${ }^{1}$ Anderson (2009) notes that the problem may also arise for other policy measures such as income taxes in industrial countries because the effects of these taxes are finely differentiated once specific exceptions are taken into account.
} 
implications of using such an approach to aggregation, taking into account the impacts on both the appropriate product weights and on tariff revenues. In Section 3, we focus on the challenges involved in applying this procedure in a global model. In Section 4, we apply our procedures to estimation of the needed tariff aggregates, and then to experiments involving partial and complete trade liberalization. Section 5 presents sensitivity analysis for the key parameters involved in the analysis. The conclusions of the study are presented in Section 6. 


\section{THE AGGREGATION APPROACH}

An important lesson from the papers by Anderson and Neary on tariff index theory is that such indexes should be based on a model that relates the index to an economic objective. In this paper, our ultimate focus is on economic welfare, although we are interested in variables such as prices and trade volumes, partly for their own sake, and partly because they influence countries' welfare through terms of trade effects. Like Bach and Martin (2001), we assume that the structure of such a competitive, small open economy can be captured by the income-expenditure condition:

$$
e(\boldsymbol{p}, u)-r(\boldsymbol{p}, \boldsymbol{v})-\left(\boldsymbol{e}_{p}-\boldsymbol{r}_{p}\right)^{\prime}\left(\boldsymbol{p}-\boldsymbol{p}^{w}\right)-f=0
$$

and the set of behavioral equations, ${ }^{2}$

$$
e_{p}(\boldsymbol{p}, u)-r_{p}(\boldsymbol{p}, \boldsymbol{v})=\boldsymbol{m}
$$

where $e(\boldsymbol{p}, u)$ is the expenditure function of the representative household; $\boldsymbol{p}$ is a vector of domestic prices; $\boldsymbol{p}^{w}$ is the corresponding vector of exogenous external prices; $u$ is domestic utility; $r(\boldsymbol{p}, \boldsymbol{v})$ is domestic revenue from production; $\boldsymbol{v}$ is a vector of productive resources; $\boldsymbol{m}$ is the vector of imports; and $f$ is an exogenously determined net financial inflow from abroad. Given this representation of the economy, we can define a balance-of-trade function, which captures the financial inflow necessary to keep utility $u$ constant when domestic prices $\boldsymbol{p}$ change (Anderson and Neary 1996) and provides a money measure of welfare changes in a small open economy.

Based on equation 1 but taking the level of utility $u^{0}$ as exogenous, $B$ can be written as:

$$
B\left(\boldsymbol{p}, u^{0}\right)=e\left(\boldsymbol{p}, u^{0}\right)-r(\boldsymbol{p}, \boldsymbol{v})-\left(\boldsymbol{e}_{p}-\boldsymbol{r}_{p}\right)^{\prime}\left(\boldsymbol{p}-\boldsymbol{p}^{w}\right)-f=0
$$

Many papers that use the balance-of-trade function to capture, for instance, the trade-restricting impact of distortions use a simple model to estimate a single aggregator such as the Trade Restrictiveness Index. Here, in contrast, we want to be able to use a two-stage modeling approach that allows us to bring in information - such as information on the structure of production and domestic demand - that is economically important, but available only at a much higher level of aggregation than data on trade and trade distortions. In this way we can combine detailed information on trade distortions with the information in many more aggregated structural models, such as econometrically estimated models of the type popularized by Kohli (2004), or with econometric (Jorgenson and Wilcoxen 1992) or calibrated (Hertel 1997) general equilibrium models.

The potential importance of such aggregation is clear when we recall that models of the type developed by Kohli have only a few sectors, and global computable general equilibrium models are typically solved with around 20 to 25 sectors. With four sectors in an estimated structural model of the type used by Kohli, there would be more than 1,300 traded goods per sector when using data on tariffs and trade at the highest degree of disaggregation available internationally - the six-digit level of the harmonized system. Even with 25 sectors, there are more than 200 traded goods per sector, and tariffs frequently vary greatly within these sectors.

In the first stage of our analysis we compute indexes that capture the information about tariffs within sectors. In the second stage, we use these indexes to solve a more aggregated model. Deaton and Muellbauer (1980) provide the theoretical underpinnings for this type of two-stage modeling. If the utility function is weakly separable, then the consumer's maximization problem can be decomposed into the maximization of subutility functions over categories of products, and at a higher level, maximization of total utility over the subutility functions. If another condition - homotheticity of preferences at the lower level - is satisfied, then two-stage budgeting can be used, with decisions at a higher level of aggregation based on aggregate prices and quantities passed up from the lower level. In a similar fashion, Chambers

\footnotetext{
${ }^{2}$ We use bold letters for vectors.
} 
(1988) and Lloyd (1994) show that weak separability of the production function and homotheticity of the sub-aggregator functions allow two-stage decisionmaking approaches to be used to represent production technologies.

In the rest of the paper we assume that the conditions needed for the formation of sub-aggregate price and quantity indexes have been met. These assumptions are inherent in use of any aggregates, such as trade-weighted averages, and are not an additional requirement of our approach relative to use of traditional aggregators.

We further assume, following Armington (1969), that domestic products are differentiated from imported products for any given composite good, such as "crops." If the prices of domestically produced goods are determined by returns on export markets, then $r(p, v)$ will be invariant to changes in tariffs, and import demand will equal $e_{p}\left(\boldsymbol{p}-\boldsymbol{p}^{w}\right)$, allowing further simplification of the model. It is useful to follow standard practice in the computable general equilibrium modeling tradition, and to assume separability between domestic and imported goods. If this is not done, the tariff revenue function may be nonmonotonic in the tariff revenue aggregator with two values of the tariff aggregator-one on each side of the peak of the Laffer curve- being consistent with any given tariff revenue. ${ }^{3}$ In the following section, we develop aggregators for the two components of the model - the expenditure and tariff revenue functionsneeded to capture the welfare impacts of tariffs in a small, open economy.

\section{The Tariff Aggregator for Expenditure}

Based on the assumptions discussed above, we can define an expenditure function consistent with each of the subutility functions used in the analysis. If $e_{i}$ is the expenditure function for commodity group $i$, then:

$$
\mathrm{e}_{\mathrm{i}}=\mathrm{e}_{\mathrm{i}}\left(\mathbf{p}_{\mathrm{i}}, \mathrm{u}_{\mathrm{i}}^{0}\right)
$$

where $\boldsymbol{p}_{i}$ is the vector of domestic prices for goods in set $i$ and $u_{i}^{0}$ is the initial utility level associated with consumption of goods in this set. Like Bach and Martin (2001), we define the tariff aggregator for expenditure on commodity group $i$ as the uniform tariff, $\tau_{i}^{e}$, which, to maintain subutility level $u_{i}^{0}$, requires the same level of expenditure on imported commodities in the group as the observed vector of commodity-specific tariffs. At any given utility level, this aggregator is optimal for measuring the impact of the tariff on domestic prices given any vector of world prices, and hence for the quantity of imports demanded and the terms of trade in a multicountry model. Since we are assuming homotheticity of the aggregator function, $e_{i}=p_{i} \cdot u_{i}$, where $p_{i}$ is the price of the composite good and $u_{i}$ is the volume of its consumption aggregated at domestic prices.

We can define the tariff aggregator for expenditure on commodity group $i$ as the uniform tariff $\tau_{i}^{e}$ :

$$
\tau_{i}^{e}=\left[\tau_{i}^{e} \mid e_{i}\left(\boldsymbol{p}_{i}^{w}\left(1+\tau_{i}^{e}\right), u_{i}^{0}\right)=e_{i}\left(\boldsymbol{p}_{i}, u_{i}^{0}\right)\right]
$$

Since the commodity aggregators that we use are defined only over traded goods, we can use the homogeneity of degree one of the expenditure function to solve for $\tau_{i}{ }^{e}$, obtaining:

$$
\tau_{i}^{e}=e_{i}\left(\boldsymbol{p}_{i}, u_{i}^{0}\right) / e_{i}\left(\boldsymbol{p}_{i}^{w}, u_{i}^{0}\right)-1 \text {. }
$$

\footnotetext{
${ }^{3}$ Since protection levels are generally determined primarily by political-economy pressures, rather than by tariff revenue goals, this ambiguity cannot be resolved by choosing the tariff rate to the left of the peak of the tariff revenue curve.
} 


\section{The Tariff Revenue Aggregator}

Bach and Martin (2001) propose a tariff revenue aggregator defined in a similar fashion to the expenditure aggregator. A tariff revenue aggregator for commodity group $i$ may be defined as the uniform tariff that will yield the same tariff revenue as the observed vector of disaggregated tariffs for that particular group of commodities, conditional on the utility level underlying the expenditure function:

$$
\tau_{I}^{R}=\left[\tau_{i}^{R} \mid \operatorname{tr}_{i}\left(\boldsymbol{p}_{i}^{w}\left(1+\tau_{i}^{R}\right), u_{i}^{0}\right)=\operatorname{tr}_{i}\left(\boldsymbol{p}_{i}, \boldsymbol{p}_{i}^{w}, u_{i}^{0}\right)\right]
$$

Manole and Martin (2005) focused on identifying a closed-form solution for this aggregator. Anderson (2009) uses a simpler approach, which we follow here, of calculating a trade-weighted average with endogenous quantity weights optimally chosen by the importer at each set of tariffs. At the initial tariff, this weighted average is the same as the conventional fixed-weight average. As tariffs change, the weights in the tariff revenue aggregator are updated using the specified import demand functions, and the two averages diverge. When multiplied by the value of imports at external prices, this weighted average, $\tau_{i}^{R}$, returns the correct value of tariff revenues for any given vector of tariff rates.

\section{Global Model Solution}

In a single-country, small-open-economy model, the tariff aggregator for expenditure can be introduced into the expenditure function, and the tariff revenue aggregator into the tariff revenue equation, and the model used to solve for the welfare impacts of changes in tariffs. When this is implemented in a global model, however, a major difficulty arises because Walras's Law is not satisfied at the global level. When, for instance, a reduction in a particularly high tariff in one country results in a more rapid decline in expenditures than in tariff revenues, the country experiences a gain in real income without there being any corresponding increase in the value of production to meet the resulting increase in demand.

This problem can be solved, following Anderson (2009), by recognizing that quantity indexes at domestic prices are different from quantity indexes at world prices. Since expenditure on aggregate good $i$ at domestic prices must equal expenditure on the good at border prices plus tariff revenue:

and hence

$$
u_{i}\left(1+\tau_{i}^{e}\right) p^{w}=x_{i}^{*}\left(1+\tau_{i}^{R}\right) p^{w}
$$

$$
u_{i}=x_{i}^{*}\left(1+\tau_{i}^{R}\right) /\left(1+\tau_{i}^{e}\right)
$$

where $u_{i}$ is the quantity of aggregate $i$ consumed in the country (defined over domestic prices); $x_{i}^{*}$ is the quantity aggregate (at world prices) exported from the rest of the world to the country of interest; and all other terms are as previously defined. 


\section{QUALITATIVE IMPLICATIONS OF AGGREGATION}

Simple theory can tell us a good deal about the likely differences between the results obtained using traditional fixed-weight and optimal aggregators. To see this, it is useful to consider the simple case when only one product is subject to a tariff. For simplicity, and without loss of generality, we set all international prices to unity, so that the domestic price of the product subject to the tariff is given by $(1+t)$. For this case, Figure 3.1 shows the marginal impacts of tariff changes on the expenditure and tariff revenue functions that determine welfare outcomes through equation (2).

To interpret Figure 3.1, it is useful to begin at the point $t_{0}, x_{0}$, which corresponds to the initial tariff, $t_{0}$, and the initial quantity of imports, $x_{0}$. The marginal impact of a small reduction in the tariff from $t_{0}$ on expenditure is $x_{0}$. Moves upward and to the left from this point along the sloping solid line labeled $x$ correspond to reductions in the tariff and increases in the quantity of the tariff-distorted good imported. When the tariff reaches zero, the weight on this good reaches $x_{1}$ under the optimal expenditure aggregator. In contrast, with the standard fixed-weight aggregator, the weight on this good stays constant at $x_{0}$ along the path to liberalization.

The marginal impact of a tariff decline on tariff revenues is given by the curve labeled $x+$ t.e $e_{p p}$. As drawn, this is initially negative - implying an increase in tariff revenues as the tariff is reducedbecause we start from a point beyond the peak revenues for this tariff. ${ }^{4}$ As the tariff reduction proceeds, the incremental increases in tariff revenues decline and turn into revenue declines where the dashed line crosses the horizontal axis. After the dashed line crosses the horizontal line corresponding to the initial level of imports, $x_{0}$, the tariff revenue aggregator shows a larger reduction in tariff revenues than the fixedweight index, despite allowing for the increases in import volumes associated with tariff declines. The marginal decline in tariff revenues remains below the decline in required expenditure until the tariff reaches zero, at which point t. $e_{p p}=0$ and hence $x=x+t \cdot e_{p p}$.

Figure 3.1-Marginal impacts of tariff reductions on expenditure and tariff revenues

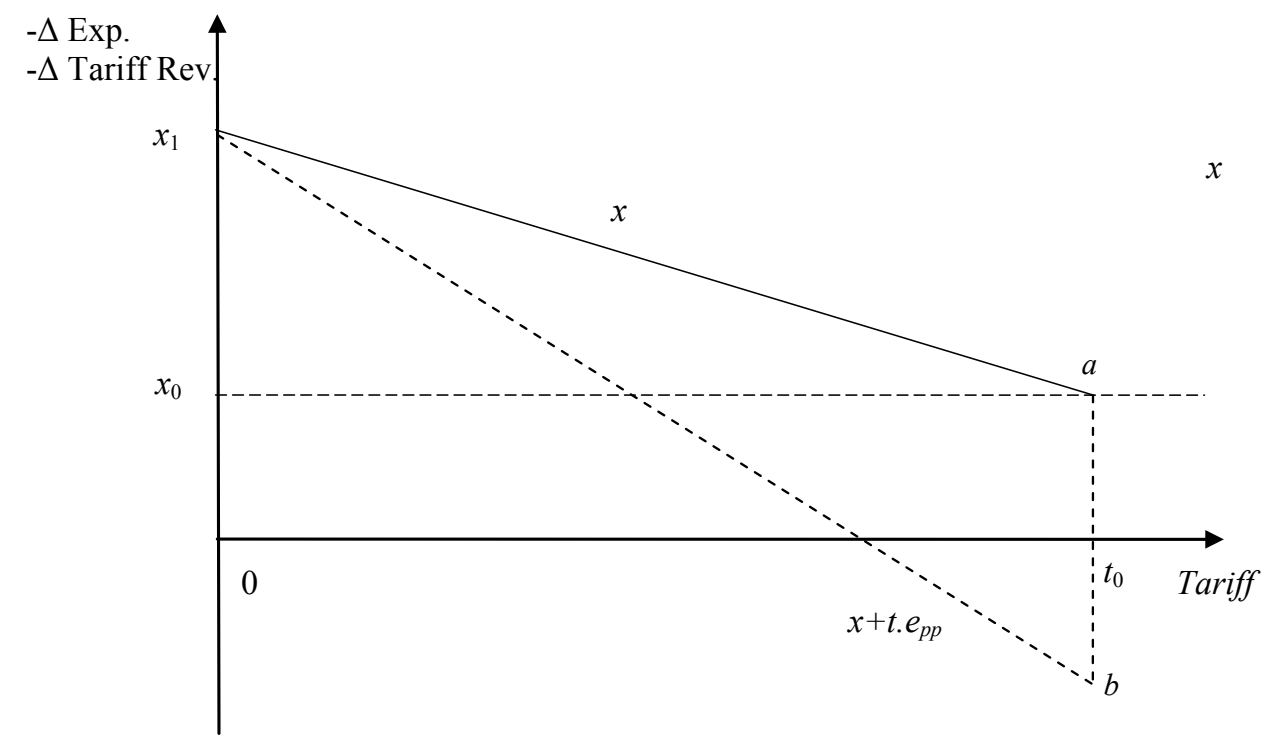

Source: Created by authors.

\footnotetext{
${ }^{4}$ Given the protectionist motivation of much protection, the relatively high estimated values of the elasticity of substitution between products at fine levels, and the high and widely dispersed patterns of tariff rates frequently observed, this case seems likely to be common.
} 
The tariff revenue effect reduces the decline in tariff revenues for any positive tariff, leaving a net gain from allowing for substitution of area $\mathrm{abx}_{1}$ in the case of full liberalization. Note that this net gain from incorporating the impact of quantity responses on economic welfare is front-end loaded, generating larger measured gains for initial liberalization than for the same tariff reductions in the later stages of reform, where tariffs are relatively low. The increase in the weight in the expenditure index does not affect the measured welfare benefits within the group because it raises both required expenditure and tariff revenues to the same degree. However, it raises the measured level of the tariff aggregator for this sector at the composite good level and hence the measured welfare impact of reform. In contrast with the tariff revenue effect, the weighting effect is likely to be much more important in the later stages of the reform, when the volume of imports has increased. 


\section{IMPLEMENTATION}

We use a two-tier strategy to implement this approach in the World Bank's LINKAGE global computable general equilibrium model (van der Mensbrugghe 2005), which has been widely used for analysis of major policy reforms. Our first step was to modify the structure of the model to distinguish between the aggregates at domestic and world prices identified in equations (8) and (9). We then calculated the tariff aggregators for expenditure and tariff revenues using the MAcMapHS6 v2.1 database (Boumellassa, Laborde, and Mitaritonna 2009), which provides detailed information on bilateral tariffs and trade flows at the HS6 level. Finally, we performed a series of simulation experiments.

\section{The Aggregation Procedure}

For concreteness, we first present a simple illustration based on a one-level aggregation problem where HS6 products are aggregated to the sectoral aggregation of the model. Then, we introduce real-world problems such as those arising from differences in the rates of protection applied on goods from different sources, where the model for an importing region is an aggregate of different countries. We focus first on the formation of aggregates for a single good, using data at the six-digit product level. ${ }^{5}$

\section{The Expenditure Aggregator}

We first illustrate our approach in the simple case where one country imports goods from only one partner, the rest of the world. The Constant Elasticity of Substitution (CES) form is an appealing choice for several reasons: (1) its simplicity and parsimony, (2) the availability of some relevant parameter estimates, and (3) the ability to handle situations where the number of firms or commodities is endogenously determined (Feenstra 1994; Zhai 2008). Using a CES aggregator for products $j$ being aggregated in group $i$, the price index for composite imported good $i$ at domestic prices is (omitting the $i$ index) given by:

$$
p=\left(\sum_{j} \alpha_{j}\left(p_{j}^{w}\left(1+t_{j}\right)\right)^{1-\sigma}\right)^{1 / 1-\sigma}
$$

where $t_{j}$ is the ad valorem tariff at the six-digit level of the harmonized system.

Since our focus in this paper is primarily on aggregation of existing products, the $\alpha_{j}$ coefficients can be inferred using standard calibration procedures (Mansur and Whalley 1984). Given these values, the value of $\tau^{e}$ can be identified using

$$
p=\left(\sum_{j} \alpha_{j}\left(p_{j}^{w}\left(1+t_{j}\right)\right)^{1-\sigma}\right)^{1 /(1-\sigma)}=\left(1+\tau^{e}\right) \cdot\left(\sum_{j} \alpha_{j}\left(p_{j}{ }^{w}\right)^{1-\sigma}\right)^{1 /(1-\sigma)}
$$

which defines $\tau^{e}$ as:

$$
\tau^{e}=\left(\sum_{j} \alpha_{j}\left(p_{j}^{w}\left(1+t_{j}\right)\right)^{(1-\sigma)}\right)^{1 /(1-\sigma) /\left(\sum_{j} \alpha_{j}\left(p_{j}{ }^{w}\right)^{1-\sigma}\right)^{1 /(1-\sigma)}-1}
$$

If we follow the usual convention in calibration of choosing units so that domestic prices equal unity, the $\alpha_{j}$ s are given by the initial value shares at domestic prices and the initial value of $\tau^{e}=\left(\sum_{j} \alpha_{j}\left(1+t_{j}\right)^{\sigma-1}\right)^{1 /(1-\sigma)}-1$

\section{Base Case: The Tariff Revenue Aggregator}

As noted above, our tariff revenue aggregator is a trade-weighted index, but differs from the standard trade-weighted index in being calculated using trade weights that adjust in response to changes in tariff rates.

\footnotetext{
${ }^{5}$ Our usage differs slightly from Broda and Weinstein's $(2006,548)$ distinction between goods at the tariff-line level and varieties supplied by individual countries because we need to distinguish between composite goods, six-digit products, and sixdigit varieties.
} 


$$
\tau^{\mathrm{R}}=\Sigma_{\mathrm{i}} \mathrm{t}_{\mathrm{i}} \mathrm{p}_{\mathrm{i}}^{\mathrm{w}} \cdot \mathrm{q}_{\mathrm{i}} / \Sigma_{\mathrm{k}} \mathrm{p}_{\mathrm{k}}{ }^{\mathrm{w}} \cdot \mathrm{q}_{\mathrm{k}}
$$

where $q_{i}=\alpha_{i}\left(p_{i} / p\right)^{-\sigma} . u$ and, in contrast with the corresponding weight in a traditional trade-weighted average, the value of $q_{i}$ adjusts as tariff rates change. $\tau^{R}$ is computed in an aggregation module independent of the global model prior to its inclusion in the global model.

\section{Practical Considerations}

Although the theoretical discussion above considers only aggregation from the finely disaggregated product level up to the composite goods used in a large-scale model, we need to take into account two other levels of aggregation in applied modeling. The first of these arises from the practical problem that some regions in most global models will be aggregates covering more than one economy. A second is that the six-digit products considered above are likely to include varieties supplied by different countries. We deal with this by using three different levels of nesting in the model.

At the highest level of aggregation, in cases where we have multiple importing countries in an importing region, we assume CES preferences across importing countries with an elasticity of substitution $\sigma_{0}$. At the second level of aggregation, we assume CES preferences over the HS6 products within the composite goods appearing in the version of the model that we use. At this stage, our HS6 products are aggregates over varieties imported from all supplying regions. At this level, we use the procedures identified in the section "The Aggregation Procedure" for the expenditure and tariff revenue aggregators, with elasticity of substitution $\sigma_{1}$. At the third level, we follow the Armington approach, assuming CES preferences across the six-digit varieties from different exporters. At this stage, we use an elasticity of substitution, $\sigma_{2}$ between the products provided by different suppliers.

\section{Parameters}

Given the approach to implementation that we have chosen, we need values of three different elasticities of substitution $\sigma_{0}, \sigma_{1}$, and $\sigma_{2}$ :

- $\sigma_{0}$ is assumed to be equal to 1 . We choose this value to hold constant each importer's share in the value of imports, primarily for want of better information.

- $\sigma_{1}$ is determined by the elasticity of substitution between imported six-digit products from all sources within a composite good — such as between apples and oranges within a composite of vegetables and fruits.

- $\sigma_{2}$ is the elasticity of substitution between varieties of six-digit products supplied by different countries/regions.

Assuming small trade shares for each product, which seems a generally reasonable approximation given that we have more than 5,000 commodities at the HS6 level, these elasticities of substitution seem likely to be close to the elasticities of demand within the group. This allows us to draw on a number of relevant sets of parameter estimates in the literature. Kee, Nicita, and Olarreaga (2008) provide estimates for import demand elasticities at the six-digit level, which average -3.12 for all HS products. These differ from the $\sigma_{1}$ elasticities that we seek in including substitution between domestic and imported varieties of the same six-digit product. Thus, if we were considering a fruit composite, we would include only substitution between imported apples, oranges, and pears, whereas the Kee, Nicita, and Olarreaga elasticities would allow substitution between domestic and imported varieties of each product. The exclusion of apples-to-apples comparisons suggests that our elasticities of substitution might be lower than the average for Kee, Nicita, and Olarreaga. However, the high level of disaggregation at which we work suggests that our elasticities of substitution should not be too much lower than the Kee, Nicita, and Olarreaga estimates.

Some other indirect evidence on the elasticities of interest is provided by Hummels and Klenow (2005, 712), drawing on Hummels (2001). They consider elasticities of substitution between varieties that are differentiated by HS six-digit product and by country of origin, concluding that these elasticities generally lie between 5 and 10. To the extent that these elasticities reflect the margins of substitution 
associated with both $\sigma_{1}$ and $\sigma_{2}$, we might expect them to be greater than our $\sigma_{1}$ elasticities of substitution but less than our desired estimates for $\sigma_{2}$. Broda and Weinstein $(2006,548)$ define varieties as goods produced by different countries, so that their elasticities of substitution are comparable to our $\sigma_{2}$ measures. They find $(2006,568)$, that the elasticity rises sharply as the categories considered become more finely distinguished. They estimate an average elasticity of substitution for products at the SITC-5 level (a slightly coarser level than HS6) of 13.1 as against 4.0 at the SITC-3 level.

In our core scenario, we use $\sigma_{1}=2$, but also consider alternative values in a sensitivity analysis. For $\sigma_{2}$, we use 10 in our base case, and also perform sensitivity analysis. 


\section{APPLICATIONS TO GLOBAL TRADE REFORM}

Two key questions are addressed in this study. The first is the broad magnitude of the difference resulting from moving from fixed-weight to optimal aggregators in practical applications. The second is the extent to which these gains are larger in the initial and the later stages of reform. To investigate these hypotheses, we consider two experiments:

- Complete global tariff liberalization.

- A partial liberalization scenario focused on cutting the highest tariffs most sharply. In particular, we use a Swiss formula (Francois and Martin 2003) to cut applied tariff rates, with country-specific coefficients computed to deliver a cut of 10 percent in the initial trade-weighted tariff for each country.

In the early stages of liberalization, the expenditure aggregator is most similar to the traditional fixed-weight aggregators but - as we have seen - the differences between the expenditure and the tariff aggregators are likely to be at their largest. As liberalization proceeds, the differences between the expenditure and the tariff revenue aggregators decline. Our first experiment covers the complete path of liberalization. The second uses a formula that leaves large gaps between the expenditure and tariff revenue aggregators by cutting only 10 percent on average, and by focusing its cuts on the highest tariffs.

To implement these simulations, we first calculate the Expenditure Aggregator Tariff $\left(\tau^{\mathrm{e}}\right)$ for each sector used in the model, and the initial trade-weighted-average tariff. Because the shares used to weight the trade-weighted average decline with the height of the tariff on any particular good, we would expect the initial trade-weighted-average tariff-which corresponds to $\tau^{\mathrm{R}}$ in the initial equilibrium - to be lower than $\tau^{\mathrm{e}}$ in cases where there is considerable variance in the tariffs within the group. Where there are some high and some low tariffs within the group, the weighted-average tariff will place a low weight on the high tariffs. In the calculation of the hypothetical uniform tariff that would be equivalent in its effects on expenditure as the observed set of tariffs, the weight on these products increases. Examples of these estimates are presented in Table 5.1 for five countries of interest.

The entries in Table 5.1 highlight some important points. The first is that the $\tau^{\mathrm{e}}$ is weakly above the initial weighted-average tariff, $\tau^{\mathrm{R}}$, but can be substantially above its level. The final row of the table, which presents the simple average of the aggregates presented above, shows that the margin of difference between the two measures is particularly large for high-income economies such as the EU and the United States, where the average tariff is low, but the dispersion of tariffs within groups is typically much higher (relative to the mean) than in developing countries. 
Table 5.1-Tariff aggregators: Tariff revenue and expenditure aggregators

\begin{tabular}{|c|c|c|c|c|c|c|c|c|c|c|}
\hline & \multicolumn{2}{|c|}{ Bangladesh } & \multicolumn{2}{|c|}{ E.U. } & \multicolumn{2}{|c|}{ India } & \multicolumn{2}{|c|}{ Japan } & \multicolumn{2}{|c|}{ U.S.A. } \\
\hline & $T^{R}$ & $\mathbf{T}^{\mathbf{e}}$ & $T^{R}$ & $\mathbf{T}^{\mathrm{e}}$ & $T^{R}$ & $T^{e}$ & $\mathbf{T}^{\mathrm{R}}$ & $T^{e}$ & $T^{R}$ & $T^{e}$ \\
\hline & $\%$ & $\%$ & $\%$ & $\%$ & $\%$ & $\%$ & $\%$ & $\%$ & $\%$ & $\%$ \\
\hline Beverages and tobacco & 32.5 & 32.5 & 14.5 & 25.5 & 91.6 & 119.3 & 13.2 & 16.1 & 5.2 & 10.0 \\
\hline Capital goods & 15.9 & 17.0 & 1.7 & 1.9 & 9.8 & 10.2 & 0.7 & 0.8 & 2.2 & 2.5 \\
\hline Chemicals, rubber, and plastics & 12.2 & 13.0 & 1.1 & 1.2 & 13.3 & 13.6 & 1.0 & 1.0 & 1.5 & 1.7 \\
\hline Fossil fuels & 26.9 & 27.4 & 0.2 & 0.2 & 11.9 & 12.3 & 0.4 & 0.4 & 0.4 & 0.4 \\
\hline Other grains & 5.2 & 5.3 & 25.5 & 39.9 & 39.3 & 51.5 & 34.4 & 43.5 & 0.1 & 0.1 \\
\hline Iron and steel & 10.2 & 11.0 & 0.2 & 0.3 & 16.0 & 16.3 & 0.5 & 0.5 & 0.1 & 0.1 \\
\hline Leather & 20.3 & 22.1 & 4.0 & 4.4 & 12.4 & 12.6 & 9.2 & 9.9 & 8.4 & 9.0 \\
\hline Livestock & 15.0 & 15.6 & 2.3 & 3.0 & 15.2 & 15.8 & 6.1 & 8.4 & 0.2 & 0.2 \\
\hline Dairy products & 32.3 & 32.3 & 55.9 & 99.5 & 33.8 & 35.1 & 40.6 & 63.0 & 30.9 & 35.1 \\
\hline Motor vehicles and parts & 17.7 & 18.1 & 4.1 & 4.4 & 19.4 & 22.4 & 0.0 & 0.0 & 1.0 & 1.0 \\
\hline Other crops & 25.7 & 26.4 & 5.9 & 31.9 & 36.8 & 45.3 & 2.5 & 12.7 & 12.2 & 19.3 \\
\hline Other food & 14.9 & 16.7 & 10.5 & 13.7 & 36.3 & 42.5 & 8.6 & 10.4 & 3.7 & 4.6 \\
\hline Other manufacturing & 20.4 & 21.3 & 0.9 & 0.9 & 14.9 & 15.0 & 0.9 & 0.9 & 0.7 & 0.7 \\
\hline Other natural resources & 11.0 & 11.8 & 0.3 & 0.4 & 13.3 & 13.6 & 1.2 & 1.3 & 0.0 & 0.1 \\
\hline Oilseeds & 7.9 & 8.0 & 0.2 & 0.2 & 44.6 & 48.1 & 0.1 & 0.1 & 2.0 & 4.7 \\
\hline Plant-based fibers & 0.5 & 0.6 & 0.0 & 0.0 & 12.2 & 12.4 & 0.0 & 0.0 & 7.7 & 8.7 \\
\hline Processed meats & 18.8 & 20.2 & 51.0 & 77.3 & 33.4 & 35.6 & 46.9 & 66.2 & 6.4 & 8.1 \\
\hline Rice & 21.9 & 22.0 & 93.9 & 110.8 & 71.2 & 73.1 & 427.3 & 551.3 & 2.9 & 3.1 \\
\hline Sugar & 27.5 & 27.7 & 105.3 & 186.7 & 84.1 & 90.0 & 160.2 & 242.2 & 24.5 & 76.5 \\
\hline Services & 22.5 & 22.5 & 0.0 & 0.0 & 15.0 & 15.0 & 0.0 & 0.0 & 0.0 & 0.0 \\
\hline Textiles & 26.7 & 27.3 & 3.5 & 4.1 & 15.5 & 15.9 & 4.3 & 4.9 & 7.0 & 7.6 \\
\hline Vegetables and fruits & 14.0 & 14.8 & 8.9 & 17.3 & 33.6 & 35.9 & 5.0 & 7.1 & 0.8 & 1.0 \\
\hline Vegetable oils and fats & 20.6 & 21.0 & 4.1 & 6.1 & 75.8 & 80.4 & 5.1 & 5.7 & 2.0 & 2.2 \\
\hline Wearing apparel & 30.3 & 30.4 & 3.5 & 4.1 & 11.7 & 12.5 & 9.8 & 9.9 & 5.4 & 6.1 \\
\hline Simple average over sectors & 18.8 & 19.4 & 16.6 & 26.4 & 31.7 & 35.2 & 32.4 & 44.0 & 5.2 & 8.5 \\
\hline
\end{tabular}

Source: Authors' estimates based on MAcMapHS6v2.1.

Welfare results obtained using our base-case elasticities are presented in Table 5.2 for full liberalization. For each indicator - real income, the terms of trade, and export volume-we display the relative changes compared to baseline with two alternative aggregators: A first column shows the results obtained using a standard version of the model with conventional weighted-average tariffs, and a second column shows the results obtained using the optimal aggregation approach with an assumed elasticity of substitution between tariff lines of $\sigma_{1}=2.0$ and of $\sigma_{2}=10$ between origins.

In Table 5.2, the average increase in the estimated welfare impacts of global trade liberalization is 76 percent at the global level, with the estimated income gains from reform rising from 0.5 percent of initial gross domestic product (GDP) to 0.88 percent. This suggests that the use of appropriate aggregation techniques is likely to be important in real-world analysis of trade reforms. However, the effect of using optimal aggregation techniques varies a great deal from one country or region to another. The gains are much larger for developing countries than for the industrial countries. For the industrial countries, the average increase in the measured welfare impact is just under 60 percent; for developing countries as a group, where initial rates of protection are higher, the corresponding gain is 124 percent. For developing countries as a group, the overall terms of trade improve by around 0.2 percent of GDP, but most of their gain (the remaining 0.52 percent of GDP) arises from increases in measured economic efficiency. For the 
industrial countries as a group, the income gain arising from terms-of-trade improvements is smaller when measured using optimal aggregators, with all of the increase in welfare coming from increases in the measured efficiency gains from reform.

Table 5.2-Results for full liberalization: Central case, changes compared to baseline

\begin{tabular}{|c|c|c|c|c|c|c|}
\hline & \multicolumn{2}{|c|}{ Real Income (\%) } & \multicolumn{2}{|c|}{ Terms of Trade (\%) } & \multicolumn{2}{|c|}{ Export Volume (\%) } \\
\hline & $\begin{array}{c}\text { Trade- } \\
\text { Weighted } \\
\text { Aggregator }\end{array}$ & $\begin{array}{c}\text { Optimal } \\
\text { Aggregator }\end{array}$ & $\begin{array}{c}\text { Trade- } \\
\text { Weighted } \\
\text { Aggregator }\end{array}$ & $\begin{array}{c}\text { Optimal } \\
\text { Aggregator }\end{array}$ & $\begin{array}{c}\text { Trade- } \\
\text { Weighted } \\
\text { Aggregator }\end{array}$ & $\begin{array}{c}\text { Optimal } \\
\text { Aggregator }\end{array}$ \\
\hline World Total & 0.50 & 0.88 & 0.00 & 0.00 & 7.1 & 8.3 \\
\hline $\begin{array}{l}\text { Low- and middle-income } \\
\text { countries }\end{array}$ & 0.58 & 1.30 & -0.28 & -0.08 & 14.8 & 16.6 \\
\hline Bangladesh & -1.44 & -1.03 & -2.26 & -2.12 & 56.6 & 61.2 \\
\hline Brazil & 1.39 & 3.18 & 1.01 & 2.52 & 16.0 & 17.5 \\
\hline Chile & 0.30 & 0.06 & 0.13 & -0.08 & 0.1 & -0.3 \\
\hline China & -0.06 & 0.17 & 0.07 & 0.42 & 14.7 & 16.2 \\
\hline Egypt & 0.24 & 5.01 & -0.76 & -0.27 & 14.8 & 21.5 \\
\hline India & 0.60 & 1.24 & -0.52 & -0.28 & 46.9 & 51.3 \\
\hline Indonesia & 0.49 & 0.69 & 0.19 & 0.18 & 11.3 & 12.4 \\
\hline Pakistan & 0.34 & -0.34 & 0.41 & -0.49 & 36.8 & 39.0 \\
\hline Thailand & 2.48 & 3.49 & 0.02 & 0.09 & 17.1 & 18.7 \\
\hline Mexico & -0.02 & 0.35 & -0.61 & -0.55 & 7.8 & 8.8 \\
\hline Nigeria & 4.68 & 6.30 & -1.95 & -1.96 & 14.1 & 14.3 \\
\hline Turkey & 1.03 & 2.21 & 0.22 & 0.76 & 9.3 & 13.8 \\
\hline Rest of Asia & 3.40 & 4.68 & -0.67 & -0.63 & 14.4 & 15.0 \\
\hline Rest of Latin America & 0.38 & 0.44 & -0.16 & -0.18 & 18.2 & 19.3 \\
\hline Morocco and Tunisia & 2.77 & 5.82 & -2.90 & -1.79 & 60.1 & 67.2 \\
\hline $\begin{array}{l}\text { Southern African Customs } \\
\text { Union }\end{array}$ & 0.96 & 2.25 & 0.04 & 0.00 & 14.5 & 19.0 \\
\hline Rest of Sub-Saharan Africa & -0.44 & -0.55 & -1.75 & -2.13 & 23.8 & 23.7 \\
\hline Rest of the world & 0.45 & 1.54 & -0.62 & -0.72 & 9.2 & 11.4 \\
\hline High-income countries & 0.48 & 0.76 & 0.08 & 0.02 & 3.9 & 4.9 \\
\hline Australia and New Zealand & 0.46 & 0.59 & 0.37 & 0.40 & 9.0 & 9.9 \\
\hline Rest of Europe & 1.53 & 3.56 & 0.42 & 0.88 & 4.7 & 7.3 \\
\hline EU 27 & 0.44 & 0.96 & -0.04 & -0.18 & 2.1 & 3.1 \\
\hline United States & 0.10 & 0.13 & 0.05 & 0.03 & 6.1 & 6.9 \\
\hline Canada & 0.05 & 0.24 & -0.30 & -0.30 & 3.0 & 4.1 \\
\hline Japan & 0.94 & 0.94 & 0.35 & 0.34 & 6.4 & 7.4 \\
\hline Korea and Taiwan & 2.99 & 3.95 & 0.27 & 0.14 & 11.9 & 14.1 \\
\hline Hong Kong and Singapore & 1.12 & 1.28 & 1.10 & 1.22 & -1.5 & -1.8 \\
\hline
\end{tabular}

Source: Authors' computation. LINKAGE model.

The increase in the estimated gains is particularly large in countries/regions such as Brazil and Egypt. These countries gain both from improvements in efficiency, when their own relatively high and variable tariffs are reduced, and from improvements in market access as trade barriers that they face are reduced. China's estimated gains rise because of increases in the estimated terms-of-trade gains. The estimated gains actually decline for Chile, whose uniform tariff structure means there are few additional measured welfare gains from improvements in efficiency. Chile faces little tariff heterogeneity in major export markets because its free trade agreements, and greater competition as tariffs, and their heterogeneity on competing suppliers are eliminated.

Table 5.3 compares the results for the Swiss formula, which reduces the highest tariffs by the most, and hence reduces the dispersion of tariffs, with the results for full global liberalization. As 
expected, the welfare gains from this initial liberalization - which reduces weighted-average tariffs by one-tenth of their initial values - are much more than one-tenth of the welfare gains from full

liberalization. In the base case, using trade-weighted-average tariff cuts, the gains are a little less than a fifth those for full trade reform. For our analysis, the key question is whether these gains are relatively larger with the optimal aggregator technique than with the trade-weighted average. From our results, it appears that the increase in welfare gains from moving to the optimal aggregators is somewhat larger than in the case of full liberalization. However, the differences are not large. For the world as a whole, the measured welfare gains are 75 percent higher for full liberalization, and 94 percent higher for the initial and sharply top-down tariff cuts associated with our Swiss formula experiment. For developing countries, the increase in this ratio is from 2.25 to 2.33 . For the high-income countries, the ratio increases from 1.59 to 1.79 .

Table 5.3-Swiss formula vs. full liberalization: Real income, central case, changes from baseline US\$million

\begin{tabular}{|c|c|c|c|c|c|c|}
\hline & \multicolumn{3}{|c|}{ Swiss Formula } & \multicolumn{2}{|c|}{ Full Liberalization } & \multirow[b]{2}{*}{$\begin{array}{c}\text { Multiplicative } \\
\text { Factor } \\
\text { (b)/(a) }\end{array}$} \\
\hline & $\begin{array}{c}\text { Trade- } \\
\text { Weighted } \\
\text { Aggregator } \\
\text { (a) }\end{array}$ & $\begin{array}{l}\text { Optimal } \\
\text { Aggregator } \\
\text { (b) }\end{array}$ & $\begin{array}{c}\text { Multiplicative } \\
\text { Factor } \\
\text { (b) } /(a)\end{array}$ & $\begin{array}{c}\text { Trade- } \\
\text { Weighted } \\
\text { Aggregator } \\
\text { (a) }\end{array}$ & $\begin{array}{c}\text { Optimal } \\
\text { Aggregator } \\
\text { (b) }\end{array}$ & \\
\hline World Total & 0.09 & 0.17 & 1.94 & 0.50 & 0.88 & 1.75 \\
\hline $\begin{array}{l}\text { Low- and middle- } \\
\text { income countries }\end{array}$ & 0.11 & 0.27 & 2.33 & 0.58 & 1.30 & 2.25 \\
\hline Bangladesh & 0.03 & 0.11 & 3.59 & -1.44 & -1.03 & 0.72 \\
\hline Brazil & 0.13 & 0.30 & 2.28 & 1.39 & 3.18 & 2.28 \\
\hline Chile & 0.00 & -0.05 & n.a. & 0.30 & 0.06 & n.a. \\
\hline China & 0.01 & 0.08 & 13.92 & -0.06 & 0.17 & sign rev. \\
\hline Egypt & 0.05 & 0.97 & 20.17 & 0.24 & 5.01 & 20.77 \\
\hline India & 0.20 & 0.31 & 1.59 & 0.60 & 1.24 & 2.05 \\
\hline Indonesia & 0.08 & 0.18 & 2.25 & 0.49 & 0.69 & 1.40 \\
\hline Pakistan & 0.10 & 0.17 & 1.66 & 0.34 & -0.34 & sign rev. \\
\hline Thailand & 0.53 & 0.69 & 1.28 & 2.48 & 3.49 & 1.40 \\
\hline Mexico & 0.06 & 0.10 & 1.73 & -0.02 & 0.35 & sign rev. \\
\hline Nigeria & 0.41 & 0.65 & 1.58 & 4.68 & 6.30 & 1.35 \\
\hline Turkey & 0.19 & 0.26 & 1.34 & 1.03 & 2.21 & 2.14 \\
\hline Rest of Asia & 0.49 & 0.94 & 1.91 & 3.40 & 4.68 & 1.38 \\
\hline Rest of Latin America & 0.06 & 0.07 & 1.26 & 0.38 & 0.44 & 1.16 \\
\hline Morocco and Tunisia & 0.71 & 1.02 & 1.44 & 2.77 & 5.82 & 2.10 \\
\hline $\begin{array}{l}\text { Southern African } \\
\text { Customs Union }\end{array}$ & 0.19 & 1.92 & 10.20 & 0.96 & 2.25 & 2.34 \\
\hline Rest of Sub-Saharan Africa & 0.06 & 0.02 & 0.42 & -0.44 & -0.55 & 1.26 \\
\hline Rest of the world & 0.09 & 0.25 & 2.61 & 0.45 & 1.54 & 3.41 \\
\hline High-income countries & 0.08 & 0.15 & 1.79 & 0.48 & 0.76 & 1.59 \\
\hline $\begin{array}{l}\text { Australia and New } \\
\text { Zealand }\end{array}$ & 0.03 & 0.04 & 1.19 & 0.46 & 0.59 & 1.29 \\
\hline Rest of Europe & 0.10 & 0.28 & 2.72 & 1.53 & 3.56 & 2.33 \\
\hline EU 27 & 0.08 & 0.17 & 2.20 & 0.44 & 0.96 & 2.17 \\
\hline United States & 0.01 & 0.03 & 2.25 & 0.10 & 0.13 & 1.36 \\
\hline Canada & 0.04 & 0.10 & 2.74 & 0.05 & 0.24 & 4.44 \\
\hline Japan & 0.13 & 0.14 & 1.08 & 0.94 & 0.94 & 1.00 \\
\hline Korea and Taiwan & 0.78 & 1.32 & 1.69 & 2.99 & 3.95 & 1.32 \\
\hline $\begin{array}{l}\text { Hong Kong and } \\
\text { Singapore }\end{array}$ & 0.07 & 0.07 & 0.93 & 1.12 & 1.28 & 1.15 \\
\hline
\end{tabular}

Source: Authors' computation. LINKAGE Model. 


\section{SENSITIVITY ANALYSIS AND CONTEXT}

Sensitivity analysis is particularly important for this paper given the exploratory nature of the analysis and the substantial uncertainty associated with estimates of the parameters that we use. Although we focus on the traditional intensive margin of response, we think it also useful to put our results in the context of the burgeoning literature on the extensive margin of adjustment, where the range of products traded responds to trade policy interventions. In this section, we begin by examining the implications of uncertainty in key parameters for our results. We then consider the magnitude of our results for disaggregation at the intensive margin relative to those emerging from the literature on extensive margin growth.

The two key parameters introduced in this paper are the elasticities of substitution between products, $\sigma_{1}$, and the elasticity of substitution between varieties of the same product supplied by different countries, $\sigma_{2}$. Table 6.1 presents estimates of the gains from global trade reform for a wide range of different values of $\sigma_{1}$; estimates for $\sigma_{2}$ are presented in Table 6.2. Focusing first on Table 6.1, we see that for the averages and for most countries, the welfare increase associated with liberalization increases steadily as $\sigma_{1}$ rises. The increase is substantial in proportional terms, with the global welfare gains rising from 0.50 percent of GDP in the standard fixed-weight index case (see Table 5.3) to 1.17 percent with $\sigma_{1}=$ 4. The gain is even larger for developing countries as a group than for the world as a whole. The gain for developing countries with $\sigma_{1}=4$ is almost three times as high as with the fixed-weight index (1.75 versus $0.58)$.

Several country exceptions to this general pattern are informative. For Chile, the estimated welfare gains decline steadily as $\sigma 1$ increases. As noted above, this is partly because Chile has-because of its policy of a uniform tariff on all nonagricultural goods-little to gain from reductions in the variability of tariffs within product groups. On the export side, it suffers from preference erosion in major markets, such as Mercosur, the United States, and the EU, with which it already has free trade agreements. As the elasticity of substitution between products increases, third-country suppliers become larger-scale competitors for Chile in markets where it has preferential access, resulting in declining benefits as $\sigma 1$ rises. The composite Rest of Sub-Saharan Africa shows a similar pattern. For both of these exporting regions, the increase in measured competition in export markets is evident in deteriorations in the terms of trade shown in the right hand side of the table. These two cases illustrate an effect under which optimal aggregation increases (slightly) the importance of tariff preference erosion.

Table 6.1—Full liberalization: Sensitivity analysis for $\sigma_{1}$

\begin{tabular}{lccc|c|cccc}
\hline & \multicolumn{4}{c|}{ Real Income, \% } & \multicolumn{4}{c}{ Terms of Trade, \% } \\
& $\boldsymbol{\sigma}_{\mathbf{1}}=\mathbf{0 . 5}$ & $\boldsymbol{\sigma}_{\mathbf{1}}=\mathbf{1}$ & $\boldsymbol{\sigma}_{\mathbf{1}}=\mathbf{2}$ & $\boldsymbol{\sigma}_{\mathbf{1}}=\mathbf{4}$ & $\boldsymbol{\sigma}_{\mathbf{1}}=\mathbf{0 . 5}$ & $\boldsymbol{\sigma}_{\mathbf{1}}=\mathbf{1}$ & $\boldsymbol{\sigma}_{\mathbf{1}}=\mathbf{2}$ & $\boldsymbol{\sigma}_{\mathbf{1}}=\mathbf{4}$ \\
\hline $\begin{array}{l}\text { World Total } \\
\quad \text { Low- and middle-income }\end{array}$ & 0.67 & 0.73 & 0.88 & 1.17 & 0.00 & 0.00 & 0.00 & 0.00 \\
$\quad$ countries & & & & & & & & \\
Bangladesh & 1.00 & 1.07 & 1.30 & 1.75 & -0.20 & -0.18 & -0.08 & 0.04 \\
Brazil & -1.03 & -1.02 & -1.03 & -1.02 & -2.08 & -2.09 & -2.12 & -2.17 \\
Chile & 1.62 & 1.97 & 3.18 & 3.63 & 1.22 & 1.51 & 2.52 & 2.96 \\
China & 0.26 & 0.20 & 0.06 & -0.06 & 0.07 & 0.02 & -0.08 & -0.19 \\
Egypt & 0.01 & 0.05 & 0.17 & 0.76 & 0.16 & 0.22 & 0.42 & 0.64 \\
India & 1.60 & 2.12 & 5.01 & 8.31 & -0.26 & -0.26 & -0.27 & -0.30 \\
Indonesia & 1.26 & 1.25 & 1.24 & 1.25 & -0.15 & -0.20 & -0.28 & -0.47 \\
Pakistan & 0.56 & 0.56 & 0.69 & 1.37 & 0.18 & 0.16 & 0.18 & 0.71 \\
$\quad$ Thailand & -0.50 & -0.44 & -0.34 & -0.10 & -0.48 & -0.48 & -0.49 & -0.51 \\
Mexico & 2.83 & 3.03 & 3.49 & 4.93 & -0.01 & 0.01 & 0.09 & 0.81 \\
Nigeria & 0.24 & 0.27 & 0.35 & 0.51 & -0.53 & -0.54 & -0.55 & -0.58 \\
$\quad$ Turkey & 5.53 & 5.76 & 6.30 & 7.10 & -1.99 & -2.00 & -1.96 & -1.86 \\
Rest of Asia & 2.16 & 2.18 & 2.21 & 2.23 & 0.81 & 0.79 & 0.76 & 0.70 \\
\hline
\end{tabular}


Table 6.1-Continued

\begin{tabular}{lcccc|cccc}
\hline & \multicolumn{3}{c}{ Real Income, \% } & \multicolumn{4}{c}{ Terms of Trade, \% } \\
& $\boldsymbol{\sigma}_{\mathbf{1}}=\mathbf{0 . 5}$ & $\boldsymbol{\sigma}_{\mathbf{1}}=\mathbf{1}$ & $\boldsymbol{\sigma}_{\mathbf{1}}=\mathbf{2}$ & $\boldsymbol{\sigma}_{\mathbf{1}}=\mathbf{4}$ & $\boldsymbol{\sigma}_{\mathbf{1}}=\mathbf{0 . 5}$ & $\boldsymbol{\sigma}_{\mathbf{1}}=\mathbf{1}$ & $\boldsymbol{\sigma}_{\mathbf{1}}=\mathbf{2}$ & $\boldsymbol{\sigma}_{\mathbf{1}}=\mathbf{4}$ \\
\hline Rest of Latin America & 0.68 & 0.62 & 0.44 & 0.42 & 0.02 & -0.03 & -0.18 & -0.25 \\
Morocco and Tunisia & 4.94 & 5.22 & 5.82 & 6.94 & -1.74 & -1.76 & -1.79 & -1.91 \\
Southern African Customs Union & 1.74 & 1.80 & 2.25 & 3.15 & -0.09 & -0.08 & 0.00 & 0.13 \\
Rest of Sub-Saharan Africa & -0.32 & -0.37 & -0.55 & -0.79 & -1.90 & -1.96 & -2.13 & -2.42 \\
Rest of the world & 1.19 & 1.30 & 1.54 & 2.03 & -0.76 & -0.76 & -0.72 & -0.61 \\
$\quad$ High-income countries & 0.58 & 0.63 & 0.76 & 1.02 & 0.06 & 0.05 & 0.02 & $-\mathbf{0 . 0 1}$ \\
Australia and New Zealand & 0.53 & 0.54 & 0.59 & 0.89 & 0.38 & 0.39 & 0.40 & 0.37 \\
Rest of Europe & 2.80 & 3.07 & 3.56 & 4.45 & 0.67 & 0.74 & 0.88 & 0.94 \\
EU 27 & 0.63 & 0.70 & 0.96 & 1.37 & -0.10 & -0.12 & -0.18 & -0.24 \\
United States & 0.12 & 0.13 & 0.13 & 0.16 & 0.04 & 0.04 & 0.03 & 0.03 \\
Canada & 0.14 & 0.18 & 0.24 & 0.24 & -0.30 & -0.31 & -0.30 & -0.22 \\
Japan & 0.86 & 0.88 & 0.94 & 1.20 & 0.34 & 0.34 & 0.34 & 0.32 \\
Korea and Taiwan & 3.22 & 3.56 & 3.95 & 4.99 & 0.27 & 0.22 & 0.14 & -0.18 \\
Hong Kong and Singapore & 1.23 & 1.25 & 1.28 & 1.27 & 1.19 & 1.20 & 1.22 & 1.18 \\
\hline
\end{tabular}

Source: Authors' computation. LINKAGE Model.

For Bangladesh and Turkey, the benefits change very little as $\sigma 1$ rises, rather than following the general pattern of rising substantially. In these cases there appears to be a balance of competing forces on the market access side; Bangladesh and Turkey benefit from preferential access to the European market, where they face the same problem as Chile. Bangladesh and Turkey differ importantly from Chile, however, in benefiting from reform of nonpreferential tariffs in major markets such as the United States.

Table 6.2 presents results on sensitivity analysis for $\sigma_{2}$. The striking feature of these results is just how little impact there is from changes in the elasticity of substitution at this level. There are two main reasons for this. The first is that tariff rates are imposed on different suppliers of the same six-digit product are much less variable than the tariffs imposed on different six-digit products within the product categories that we use. The second is that our modeling strategy involves much less aggregation across regions than it does across commodities.

Although there are relatively few cases where the value of $\sigma_{2}$ affects the results substantially, some of these cases are informative. Bangladesh is one such case, where all of the additional income gains arise from terms-of-trade improvements. These gains are consistent with Bangladesh exporting substantial quantities of textiles and clothing to Europe under tariff preferences, while exporting substantial quantities to other markets, such as the United States, over relatively high tariffs. When Bangladeshi producers can respond to progressively lower tariffs, the measured terms-of-trade gains over the path to full liberalization are greater than if the export mix within product groups is held constant at its initial level. Similar issues regarding preferences arise in the composite region for the Rest of Sub-Saharan Africa, where the terms-of-trade losses associated with preference erosion and rising prices of imports such as food are pared back when optimal aggregators are used. In this case, not all of the increase in real income is obtained from improvements in the terms of trade. For a composite region such as this, additional welfare gains can be expected on the import side because of the differences in the tariffs levied by different members of the group. Given these differences in tariff rates, our optimal aggregator technique can be expected to report higher welfare gains from tariff reforms. The case of "Rest of Asia" is particularly interesting as our aggregators result in smaller welfare gains. The reduction in the real income gains is exactly accounted for by deterioration in the terms of trade, driven at least in part by increasing import prices as the share weights on imported goods rise. 
Table 6.2- Full liberalization: Sensitivity analysis for $\sigma_{2}$

\begin{tabular}{|c|c|c|c|c|c|c|}
\hline & \multicolumn{3}{|c|}{ Real Income, \% } & \multicolumn{3}{|c|}{ Terms of Trade, $\%$} \\
\hline & $\sigma_{2}=6$ & $\sigma_{2}=10$ & $\sigma_{2}=14$ & $\sigma_{2}=6$ & $\sigma_{2}=10$ & $\sigma_{2}=14$ \\
\hline World Total & 0.87 & 0.88 & 0.88 & 0.00 & 0.00 & 0.00 \\
\hline Low- and middle-income countries & 1.29 & 1.30 & 1.30 & -0.08 & -0.08 & -0.08 \\
\hline Bangladesh & -1.31 & -1.03 & -0.90 & -2.33 & -2.12 & -2.01 \\
\hline Brazil & 3.19 & 3.18 & 3.17 & 2.53 & 2.52 & 2.51 \\
\hline Chile & 0.07 & 0.06 & 0.05 & -0.08 & -0.08 & -0.09 \\
\hline China & 0.17 & 0.17 & 0.17 & 0.43 & 0.42 & 0.42 \\
\hline Egypt & 5.01 & 5.01 & 5.00 & -0.26 & -0.27 & -0.27 \\
\hline India & 1.24 & 1.24 & 1.23 & -0.28 & -0.28 & -0.29 \\
\hline Indonesia & 0.69 & 0.69 & 0.69 & 0.18 & 0.18 & 0.18 \\
\hline Pakistan & -0.33 & -0.34 & -0.34 & -0.49 & -0.49 & -0.49 \\
\hline Thailand & 3.49 & 3.49 & 3.48 & 0.10 & 0.09 & 0.08 \\
\hline Mexico & 0.34 & 0.35 & 0.36 & -0.55 & -0.55 & -0.55 \\
\hline Nigeria & 6.29 & 6.30 & 6.31 & -1.97 & -1.96 & -1.96 \\
\hline Turkey & 2.20 & 2.21 & 2.21 & 0.76 & 0.76 & 0.77 \\
\hline Rest of Asia & 4.93 & 4.68 & 4.55 & -0.38 & -0.63 & -0.76 \\
\hline Rest of Latin America & 0.39 & 0.44 & 0.48 & -0.22 & -0.18 & -0.15 \\
\hline Morocco and Tunisia & 5.81 & 5.82 & 5.84 & -1.78 & -1.79 & -1.79 \\
\hline Southern African Customs Union & 2.24 & 2.25 & 2.26 & -0.01 & 0.00 & 0.01 \\
\hline Rest of Sub-Saharan Africa & -0.63 & -0.55 & -0.44 & -2.19 & -2.13 & -2.05 \\
\hline Rest of the world & 1.51 & 1.54 & 1.55 & -0.73 & -0.72 & -0.71 \\
\hline High-income countries & 0.76 & 0.76 & 0.76 & 0.02 & 0.02 & 0.02 \\
\hline Australia and New Zealand & 0.61 & 0.59 & 0.58 & 0.42 & 0.40 & 0.40 \\
\hline Rest of Europe & 3.55 & 3.56 & 3.57 & 0.87 & 0.88 & 0.88 \\
\hline EU 27 & 0.95 & 0.96 & 0.95 & -0.18 & -0.18 & -0.18 \\
\hline United States & 0.13 & 0.13 & 0.13 & 0.03 & 0.03 & 0.03 \\
\hline Canada & 0.24 & 0.24 & 0.24 & -0.30 & -0.30 & -0.31 \\
\hline Japan & 0.92 & 0.94 & 0.94 & 0.34 & 0.34 & 0.35 \\
\hline Korea and Taiwan & 3.94 & 3.95 & 3.95 & 0.14 & 0.14 & 0.14 \\
\hline Hong Kong and Singapore & 1.25 & 1.28 & 1.30 & 1.21 & 1.22 & 1.24 \\
\hline
\end{tabular}

Source: Authors' computation. LINKAGE Model.

Although the aggregators that we use would allow incorporation of the impacts of changes in the range of products traded, our focus in this paper has been exclusively on the intensive margin of adjustment, where the quantities of currently traded goods adjust to the changes in distortions. Our analysis allows an initial comparison of the importance of the problem of aggregation bias in global general equilibrium modeling relative to the problems associated with omission of the extensive margin of new product introduction.

A recent econometric study by Debaere and Mostashari (2010) concludes that modest liberalization by an importing country appears to have little impact on the range of products imported. Over the period from 1996 to 2006, they find that the share of manufactured imports into the United States attributable to new goods was less than 12 percent. From their econometric analysis, they conclude that between 5 and 12 percent of this increase in the number of traded goods could be explained by reductions in US tariffs. Given the high elasticities of substitution that appear to apply to substitution between 
varieties, the welfare gains associated with increasing variety that result from trade liberalization are likely, in this situation, to be quite small. ${ }^{6}$ Recent empirical work by Kehoe and Ruhl (2009) emphasizes the expansion in the volume of new products, but finds this to be large only in cases where one or both of a pair of trading partners undergoes a major structural transformation, and to be small for modest trade liberalizations. Simulation analysis by Zhai (2008), building on the Melitz model assumptions, concluded that allowing for increases in product variety picks up the welfare gains from own-liberalization, and concluded that liberalization could roughly double the welfare gains of global reform relative to standard approaches to trade liberalization.

This brief survey of the emerging literature on extensive-margin implications of trade liberalization suggests that the question of aggregation on which we focus appears to be quite important relative to the impacts of extensive margin growth in varieties. Our result that the welfare gains from global trade reform are likely to roughly double once aggregation at the intensive margin is undertaken properly seems to be roughly as important as including extensive margin growth was in the Zhai (2008) model. For modest trade liberalization, it seems likely to be at least as important as the results obtained in the empirical literature on extensive margin growth and trade liberalization. Further, the two approaches are not mutually exclusive - our aggregators allow for expansion in product variety if the remaining components of the modeling framework can represent this phenomenon, as in Zhai (2008).

\footnotetext{
${ }^{6}$ Feenstra (1994) shows, using a Dixit-Stiglitz framework, that the welfare gain when new varieties account for an x percent expansion of imports is $(1+\mathrm{x})^{1 /(\sigma-1)}$.
} 


\section{CONCLUSIONS}

It has always been clear that the crude trade-weighted-average approach to aggregation used in almost all quantitative modeling of the benefits of trade reform wastes valuable information that is available in the detailed data on trade and trade distortions. Despite this, many applied studies continue to be based on crude aggregates of around 25 products chosen for tractability and consistency with production and consumption data that are generally available only at much higher degrees of aggregation. In this study, we use the broad approach to aggregation developed by Bach and Martin (2001) to deal with the problem of aggregation when protection rates vary substantially within the groups used in the analysis. Under this approach, we form distinct aggregates for both expenditure on goods and tariff revenues, distinguishing, following Anderson (2009), between quantity aggregates at domestic and international prices.

Before applying the approach, we first consider its implications using a simple, graphical approach. We show that the use of optimal aggregators has two important implications. Within each aggregate group used, the marginal impact of a tariff reduction on expenditures will be greater than its marginal impact on tariff revenues, since each reduction in tariffs increases the volume of imports on which tariffs are collected. This difference allows us to capture true welfare gains that are omitted when using traditional trade-weighted averages, and that decline as liberalization proceeds. However, as tariffs decline, rising weights on tariffs that have experienced large tariff reductions increase the weights on reductions in these tariffs. This raises a question that we address in the analysis - of whether optimal aggregators have a larger impact when considering complete tariff liberalization or in the initial stages of liberalization.

To provide an answer to the questions posed, we apply the technique, using detailed tariff information provided by the MAcMapHS6v2.1 database, in a modified version of the LINKAGE global general equilibrium model, taking into account the nested structure of import demand in that model. Using this aggregation procedure with a conservative estimate of the elasticity of substitution between six-digit tariff lines results in a substantial increase - close to a doubling - in the estimated welfare gains from complete liberalization of global trade barriers both for aggregate country groups and most individual countries. The impact is not the same across countries, with some of the exceptions providing important insights. Perhaps the most interesting exception is Chile, where the low variability of tariffs means conventional aggregation causes little understatement of the welfare gains from own-liberalization, while picking up stronger adverse impacts from tariff preference erosion in markets subject to free trade agreements. Comparison of our results with the latest available estimates of the implications of allowing for extensive margin growth suggests that using optimal aggregators is likely to be as important as accounting for the effects of extensive margin growth in the range of varieties traded. The two approaches are, of course, not mutually exclusive and our nested Dixit-Stiglitz approach to representing preferences over products and varieties provides a potential basis for capturing the implications of changes in the range of varieties traded.

Sensitivity analysis on the key parameters suggests that the elasticity of substitution between sixdigit products, for which there is substantial variability in protection rates, has a much greater influence on the welfare results than the elasticity of substitution between suppliers of different varieties of the same product. The strength of this result suggests that econometric work to obtain better estimates of the relevant elasticities should focus on substitution between tariff lines, rather than between suppliers. Another priority for further work appears to be extending models to take into account both proper aggregation across tariffs and endogenous changes in the ranges of product varieties traded. 


\section{REFERENCES}

Anderson, J. E. 2009. “Consistent Trade Policy Aggregation.” International Economic Review 50 (3): 903-927.

Anderson, J. E., and J. P. Neary. 1994. "Measuring the Restrictiveness of Trade Policy." World Bank Economic Review 8 (2): 151-169.

—. 1996. "A New Approach to Evaluating Trade Policy.” Review of Economic Studies 63 (1): 107-125. . 2003. "The Mercantilist Index of Trade Policy." International Economic Review 44:627-649.

Armington, P. 1969. "A Theory of Demand for Products Distinguished by Place of Production.” IMF Staff Papers 16 (1): 159-178.

Bach, C., and W. Martin. 2001. "Would the Right Tariff Aggregator for Policy Analysis Please Stand Up?” Journal of Policy Modeling 23 (6): 621-635.

Bach, C., W. Martin, and J. Stevens. 1996. "China and the WTO: Tariff Offers, Exemptions, and Welfare Implications." Review of World Economics 132 (3): 409-431.

Boumellassa, H., D. Laborde, and C. Mitaritonna. 2009. A Picture of Tariff Protection across the World in 2004: MAcMap-HS6, Version 2. IFPRI Discussion Paper 903. Washington, DC: International Food Policy Research Institute.

Broda, C., and D. Weinstein. 2006. "Globalization and the Gains from Variety." Quarterly Journal of Economics 121 (2): 541-585.

Chambers, R. 1988. Applied Production Analysis: A Dual Approach. Cambridge: Cambridge University Press.

Deaton, A., and J. Muellbauer. 1980. Economics and Consumer Behavior. Cambridge: Cambridge University Press.

Debaere, P., and S. Mostashari. 2010. "Do Tariffs Matter for the Extensive Margin of International Trade? An Empirical Analysis." Journal of International Economics 81:163-169.

Feenstra, R. 1994. "New Product Varieties and the Measurement of International Prices." American Economic Review 84 (1): 157-177.

Francois, J., and W. Martin. 2003. "Formula Approaches for Market Access Negotiations.” World Economy 26 (1): $1-28$.

Hertel, T. 1997. Global Trade Analysis: Modeling and Applications. New York: Cambridge University Press.

Hummels, D. 2001. "Towards a Geography of Trade Costs.” Mimeo, Purdue University. http://www.krannert.purdue.edu/faculty/hummelsd/research/toward/TGTC.pdf.

Hummels, D., and P. Klenow. 2005. "The Variety and Quality of a Nation's Exports." American Economic Review 95 (3): 704-723.

Jorgenson, D., and P. Wilcoxen. 1992. "Reducing U.S. Carbon Emissions: An Econometric General Equilibrium Assessment." Resource and Energy Economics 15:17-25.

Kee, H. L., A. Nicita, and M. Olarreaga. 2008. "Import Demand Elasticities and Trade Distortions." Review of Economics and Statistics 90 (4): 666-682.

Kehoe, T., and K. Ruhl. 2009. How Important Is the New Goods Margin in International Trade? Federal Reserve Bank of Minneapolis, Research Department Staff Report 324, Minneapolis.

Kohli, U. 2004. "Real GDP, Real Domestic Income, and Terms-Of-Trade Changes." Journal of International Economics 62 (1): 83-106.

Lloyd, P. 1994. “Aggregation by Industry in High-Dimensional Models.” Review of International Economics 2 (2): 97-111.

Manole, V., and W. Martin. 2005. "Keeping the Devil in the Details: A Feasible Approach to Aggregating Trade Distortions." Paper presented at the meeting of the European Trade Study Group, Dublin, September. 
Mansur, A., and J. Whalley. 1984. "Numerical Specification of Applied General Equilibrium Models: Estimation, Calibration and Data." In Applied General Equilibrium Analysis, edited by H. Scarf and J. Shoven., pp. 69-127. Cambridge: Cambridge University Press.

Martin, W., D. van der Mensbrugghe, and V. Manole. 2003. Is the Devil in the Details?: Assessing the Welfare Implications of Agricultural and Nonagricultural Trade Reforms. World Bank Working Paper. Washington, DC: World Bank.

van der Mensbrugghe, D. 2005. "LINKAGE Technical Reference Document, Version 6.0." http://siteresources.worldbank.org/INTPROSPECTS/Resources/3349341100792545130/LinkageTechNote.pdf.

Zhai, F. 2008. “Armington Meets Melitz: Introducing Firm Heterogeneity in a Global CGE Model of Trade.” Journal of Economic Integration 23 (3): 575-604. 





\section{RECENT IFPRI DISCUSSION PAPERS}

\section{For earlier discussion papers, please go to http://www.ifpri.org/publications/results/taxonomy\%3A468.}

All discussion papers can be downloaded free of charge.

1122. Managing future oil revenue in Uganda for agricultural development and poverty reduction: A CGE analysis of challenges and options. Manfred Wiebelt, Karl Pauw, John Mary Matovu, Evarist Twimukye, and Todd Benson, 2011.

1121. Impacts of an early education intervention on students' learning achievement: Evidence from the Philippines. Futoshi Yamauchi and Yanyan Liu, 2011.

1120. Supply and demand for cereals in Nepal, 2010-2030. Sanjay K. Prasad, Hemant Pullabhotla, and A. Ganesh-Kumar, 2011.

1119. Which trade integration scheme can best help Sub-Saharan Africa develop and export more processed agricultural goods?. Mathilde Douillet, 2011.

1118. Women cotton farmers - Their perceptions and experiences with transgenic varieties: A case study for Colombia. Patricia Zambrano, Jorge H. Maldonado, Sandra L. Mendoza, Lorena Ruiz, Luz Amparo Fonseca, and Iván Cardona, 2011.

1117. Can water allocation in the Yellow River basin be improved?: Insights from a multi-agent system model. Ximing Cai, YiChen E. Yang, Jianshi Zhao, and Claudia Ringler, 2011.

1116. Using the regression discontinuity design with implicit partitions: The impacts of Comunidades Solidarias Rurales on schooling in El Salvador. Alan de Brauw and Daniel Gilligan, 2011.

1115. The quiet revolution in India's food supply chains. Thomas Reardon and Bart Minten, 2011.

1114. A review of input and output policies for cereals production in Nepal. Hemant Pullabhotla, Ganga Shreedhar, A. GaneshKumar, and Ashok Gulati, 2011.

1113. Do shocks affect men's and women's assets differently?: A review of literature and new evidence from Bangladesh and Uganda. Agnes R. Quisumbing, Neha Kumar, and Julia A. Behrman, 2011.

1112. Overcoming successive bottlenecks: The evolution of a potato cluster in China. Xiaobo Zhang and Dinghuan Hu, 2011.

1111. The impact of land titling on labor allocation: Evidence from rural Peru. Eduardo Nakasone, 2011.

1110. A multiregion general equilibrium analysis of fiscal consolidation in South Africa. Margaret Chitiga, Ismael Fofana, and Ramos Mabugu, 2011.

1109. How far do shocks move across borders?:Examining volatility transmission in major agricultural futures markets. Manuel A. Hernandez, Raul Ibarra, and Danilo R. Trupkin, 2011.

1108. Prenatal seasonality, child growth, and schooling investments: Evidence from rural Indonesia. Futoshi Yamauchi, 2011.

1107. Collective Reputation, Social Norms, and Participation. Alexander Saak, 2011.

1106. Food security without food transfers?: A CGE analysis for Ethiopia of the different food security impacts of fertilizer subsidies and locally sourced food transfers. A. Stefano Caria, Seneshaw Tamru, and Gera Bizuneh, 2011.

1105. How do programs work to improve child nutrition?: Program impact pathways of three nongovernmental organization intervention projects in the Peruvian highlands. Sunny S. Kim, Jean-Pierre Habicht, Purnima Menon, and Rebecca J. Stoltzfus, 2011.

1104. Do marketing margins change with food scares?: Examining the effects of food recalls and disease outbreaks in the US red meat industry. Manuel Hernandez, Sergio Colin-Castillo, and Oral Capps Jr., 2011.

1103. The seed and agricultural biotechnology industries in India: An analysis of industry structure, competition, and policy options. David J. Spielman, Deepthi Kolady, Anthony Cavalieri, and N. Chandrasekhara Rao, 2011.

1102. The price and trade effects of strict information requirements for genetically modified commodities under the Cartagena Protocol on Biosafety. Antoine Bouët, Guillaume Gruère, and Laetitia Leroy, 2011

1101. Beyond fatalism: An empirical exploration of self-efficacy and aspirations failure in Ethiopia. Tanguy Bernard, Stefan Dercon, and Alemayehu Seyoum Taffesse, 2011.

1100. Potential collusion and trust: Evidence from a field experiment in Vietnam. Maximo Torero and Angelino Viceisza, 2011. 
INTERNATIONAL FOOD POLICY

\section{RESEARCH INSTITUTE}

www.ifpri.org

IFPRI HEADQUARTERS

$2033 \mathrm{~K}$ Street, NW

Washington, DC 20006-1002 USA

Tel.: +1-202-862-5600

Fax: +1-202-467-4439

Email: ifpri@cgiar.org 